Draft $-1^{\text {st }}$ Draft

\title{
Queering (inter-sectarian) Heterosexual Love in Lebanon
}

\begin{abstract}
.
This paper draws on a yearlong ethnography conducted among cis heterosexual couples in contemporary urban Lebanon in order to examine the links between romantic love and the category of sect. The paper embraces a political understanding of love and recognizes emotions as a valid source knowledge. It puts personal narratives of "impossible" intersectarian love stories in conversation with queer temporality scholarship in order to recognize the political scope of inter-sectarian love. This paper argues that in the absence of a serious project of national reconciliation, inter-sectarian love, despite its short lifespan, constitutes restorative instances in post- civil war Lebanon.
\end{abstract}

I met Aline ${ }^{1}$ a week to the day since her khutūbah ${ }^{2}$ to Wael. Before Wael, an Orthodox Christian like her, Aline dated Diya, a Shi'a Muslim, for six years during her university studies towards a degree in architecture. According to Aline, she and Diya "clicked on every level." 3 Not only was Diya from a "good family," unlike the majority of Shi'a male youth in Lebanon, he "was not invested in Hezbollah ${ }^{4}$ and their politics." When Diya suggested it was time to disclose their relationship to their immediate family, Aline, unlike Diya, felt particularly anxious:

I simply couldn't introduce him to my mother. Or my father. Or anyone, for that matter. I spoke to my uncle [paternal] about him at first. My uncle never married. He is well-travelled and has life experience. He always struck me as open-minded. My parents are not mit'așbìn [fundamentalist], but they are very traditional people. ${ }^{6}$

\section{INTRODUCTION}


Draft $-1^{\text {st }}$ Draft

In a 2013 paper published in the International Journal of Middle East Studies, Mikdashi called for "queering" Middle Eastern studies, and to embrace queer theory as methodology, or a "a way of interrogating normative practices of and assumptions about race, class, the state, and the body." ${ }^{, 7}$ Mikdashi developed her argument from the critique of the myth of the "universal unmarked citizen." ${ }^{\prime 8}$ Following Mikdashi, this myth reproduces the space between state and citizens as equal, "ungendered," and "unclassed". Instead, Mikdashi captures the rather uneven relationship between the Lebanese state and its citizens in her ethnographic examination of "strategic [sect] conversions" in Lebanon, a largely gendered, sexed, classed, and religious (read sect) practice, which draws on the 18 personal status laws available to Lebanese women and men. ${ }^{10}$ In a minute analysis of prior legal cases, Mikdashi shows that if and when the Lebanese state intervenes in decisions made by personal status courts, it is strictly to "protect the rights of the citizen" from "procedural (or administrative) abuses." "As a result, Mikdashi concludes, and rightly so, that the Lebanese state "already is" a secular space. Theoretically speaking, Mikdashi distinguishes between the "madhab," the state's legal form of recognition or one's personal status, and "sect," the socio-politically perceived form of belonging. Mikdashi's distinction is crucial because it challenges mainstream portrayals of Lebanon as "stuck" in a sectarian deadlock. Mikdashi supports her argument through several examples of "strategic sectarian conversion" - a surprisingly straightforward, and uncomplicated procedure when juxtaposed with Lebanon's "sectarian mess." Following Mikdashi, "neither sect nor personal status necessarily reflects one's religious beliefs and practices." ${ }^{\prime 12}$ Moreover, if a citizen chooses not to identify with their sect, or with their gender vis-à-vis the wider society, they will still be socially and legally recognized by the state as per their personal status and sex, the two very "technologies of recognition that the Lebanese census and the state follow." 13 Still, my empirical work informed me that despite the simplicity of sectarian conversion, the reality is notably more complex. In what follows, I 
Draft $-1^{\text {st }}$ Draft

draw on empirical data in order to show the unevenness of and messy links between love as a feeling and sect in Lebanon.

Romantic heterosexual love ${ }^{14}$ shapes global economies, ${ }^{15}$ regulates Publics, ${ }^{16}$ and dictates our present towards a reproductive type of futurity. ${ }^{17}$ Still, there exists a "lack of public discussion"18 about it. This lack is not entirely surprising seeing the "hetero"19 and "chrono" normative ${ }^{20}$ order that organizes our daily lives. Our bodies are timed and relentlessly geared towards fulfilling specific societal expectations in particular times and places: from graduating from school or university, for instance, to getting hired, married, or having children. When a particular order is hyper-normalized both in time and space, it is taken as given. It becomes the signifier against which derivative and divergent ways of doing, being, seeing, and feeling are measured. That is, this order is reproduced following a logic of sameness: what comes next must originate from and reproduce sameness. What happens, then, when an imperative is breached? What happens to those involved? What traces remain, if any? And how do we invest them towards a least closely-defined and most inclusive future?

The particular normative order I focus on in this work is inter-sectarian marriage, a deeply ingrained institution in contemporary Lebanon. Conversely, I identify inter-sectarian love, exemplified by Aline above, as its anti-thesis. Marriage and love as seemingly diverging poles emerged from my empirical investigation of heterosexual romantic love in Lebanon between 2014 and 2015. I conducted in-depth and life interviews with a total of twenty-eight cis heterosexual couples, both jointly and separately, over a period of one year and in intervals of two months, as a way for me to chart and track their love trajectories. ${ }^{21}$ My larger research was concerned with the political economy of the period of courtship in Lebanon, including financial, affective, and parental negotiations. The findings I relate in this paper are a byproduct of my larger research. They are the synthesis of the reminiscent fashion in which inter-sectarian love stories were unanimously narrated to me by my interlocutors. For many of 
Draft $-1^{\text {st }}$ Draft

my interlocutors, sect constitutes a "border," in the Gloria Anzaldúa sense, that separates "the safe from the unsafe," ${ }^{22}$ and the same from the else. Conversely, I am interested in the space in-between love and marriage.

Inter-sectarian love, following my research, remains a marginalized and marginalizing intimacy that both society and the legal realm discriminate about. In this work, I argue that we view inter-sectarian love stories as reconciliatory instances in post- civil war Lebanon's discursively-taught (dis)affectivities, where romantic attachments to specific others is taught and conditioned from an early age along intra-sectarian and hetero-normative lines. Seeing its potential of destabilizing normative intra-sectarian connectivity and its projection towards "impossible" ${ }^{, 23}$ others, this paper recognizes the reconciliatory potential of (inter-sectarian) heterosexual romantic love in post- civil war Lebanon, and thus views it as a "queer" affect, or a "futurity" that is yet to be: ${ }^{24}$

Queerness is essentially about the rejection of a here and now and an insistence on potentiality or concrete possibility for another world. ${ }^{25}$

In support of my argument, my paper proceeds as follows. I first critically examine the existing literature on love in the Middle East and elsewhere two-fold (empirically and theoretically) in order to stress the "spatial, relational, and political" 26 dimensions of love. That is, I understand love as a unison of the material and the imagined, the real and the virtual, the collective and the individual. My either/and understanding of love is crucial for an optimum engagement with my interlocutors' narratives and the larger political landscape. Drawing on empirical data, I then identify the timeline of love in Lebanon in order to distinguish it from marriage. Far from defining each, I focus on what they do: whereas marriage territorializes, love is capable of containing the surplus that exceeds societal equation of marriage with reason, maturity, and communal fostering. I here prioritize in my analysis the social category of sect in order to understand how differential affectivities are (re)produced in Lebanon. At a third stage, I draw on queer temporality scholarship in order to 
Draft $-1^{\text {st }}$ Draft

argue that in the absence of a serious project of national reconciliation, love constitutes reconciliatory instances in post- civil war Lebanon. Ultimately, my paper attempts to answer the call of Maya Mikdashi to "queer" Middle Eastern studies. ${ }^{27}$ In addition, it contributes to the growing literature that examines the Middle East from an affective lens. ${ }^{28}$

\section{LOVE AND THE EXISTING LITERATURE}

The absence of a canonical definition for love has caused academic "anxiety" 29 and "discomfort." 30 The notion of love as a "master trope" that is "as pervasive as it is variable" 31 is a highly productive tool for social analysis, especially gender relations, because it reveals some of the most basic ways that human societies organize social life, including marriage, as well as how individuals enact, resist, or transform social discourses of love. What's more, the question of "when, whom, and how one marries all have implications for gender relations within society." 32 This point rings particularly true in the context of love-marriage in Lebanon, seeing the "sectarian" element that define it, not barring gender, class, and further social categories.

Three broad strands can be said to characterize the existing literature on love. ${ }^{33}$ The first strand can be found in anthropological works invested in assessing the universality of romantic love, notably its existence outside of the west. ${ }^{34}$ Unsurprisingly, western hegemonic patterns of love are taken as a referent-framework against which further cultures and contexts are measured, sometimes in "inferior" terms. ${ }^{35}$ Equally, in a recent special section in the Arab Studies Journal on romantic love in the Middle East, the editors relate Euro-American anxieties about Muslim's fertility in order to critique the view that relegates romantic love to a strictly Euro-American setting. ${ }^{36}$ The flaky boundaries between love as a feeling and the reproductive outcome of marriage compel us to embrace sexuality as a domain of 
Draft $-1^{\text {st }}$ Draft

"restriction," "repression," and "agency" terrain in which groups struggle to alter sexual arrangements and ideologies." 38

A second strand of the literature on love works through a "political economy" framework. This strand recognizes the entanglement of love with global market forces and thus theorizes love as a commodity. ${ }^{39}$ We learn from this literature that the "modernity" of romantic love in non-western settings, illustrated in the insistence on choosing one's life-partner is the result of increasingly individual selves who emerge in conjunction with an increasingly borderless and globalized world. The question of choice and agency, as opposed to arranged marriages and kin pressure, has come to characterize love interpretations in contemporary non-western settings, including India, ${ }^{40}$ Korea, ${ }^{41}$ China, ${ }^{42}$ Jordan, ${ }^{43}$ Egypt,${ }^{44}$ and Morocco. ${ }^{45}$ In the Middle East, a "political economy" approach informed the work of Homa Hoodfar" ${ }^{46}$ and Diane Singerman ${ }^{47}$ in Egypt, and of Frances Hasso in the UAE. ${ }^{48}$ Such works uncover the enmeshment of romantic love with power structures, notably gender, class, parental approval, religion (in the moral sense, oftentimes by contrasting traditional practices of courtship with modern ones, for instance), and social standing. It is important to note though, that the boundaries between the couple and their kin, tradition and modernity, old and new, are not always in opposition, and their formation is highly dependent on the context in question and the power dynamics involved.

The third strand of the literature examine the racialized dimension of love by paying attention to power dynamics within it. Such works acknowledge the intersection of love with the nation, or the processes by which exclusionary/inclusionary attachments are produced. Unsurprisingly, this literature is highly relevant for the purpose of my work, seeing the relevance of sect to young men and women's experience and imagination of love. In the Lebanese context, for instance, Lebanese women who marry foreign men have no right to pass their Lebanese citizenship to their children; the same does not apply to men who marry 
Draft $-1^{\text {st }}$ Draft

non-Lebanese women. In addition to showcasing the gendered (read unequal) outcome of Lebanese citizenship, this state of affairs reveals how Lebanese men and women are taught to attach negative (or positive) affects to well-identified bodies from an early age. In the same vein, we learn from Charu Gupta that the Hindu right in India capitalizes on what has become known as "Love Jihad" in its anti-Muslim deployment. ${ }^{49}$ Similar anxieties related to fertility rates can be captured in the context of Lebanon. The myth of Lebanon's delicate Muslim/Christian balance, which can be traced back to the 1932 Census under the French mandate ${ }^{50}$ or the fear of Hezbollah's partisans' high fertility rate are common conversation topics in Lebanese society, in addition to impacting the bio-politics of local-sectarian authorities. ${ }^{51}$

Elsewhere in the Middle East, the notion of love is often examined in tandem with processes related to the questions of modernity and nation-building. This literature pays particular attention to the simultaneity of power dynamics and the historical specificity of their context in its examination of emotions. I go as far as arguing that this literature predates what has become known as the "affective turn" 52 in cultural studies, a point I return to shortly, in addition to unveiling the debates we encounter in contemporary studies of emotions and affects. Afsaneh Najmabadi, for instance, shows how love was relocated from a homo to a hetero setting in order to redeploy it as an ideal between husband and wife in a step towards reinforcing the model of the modern nuclear family during the era of nation-building in Iran. ${ }^{53}$ During the late 20th century, orientalist depictions of love practices in Egypt abounded in travelogues and in the writings of western missionaries, and native Egyptian modernists. Leila Ahmed notes how western missionaries to Egypt portrayed marriage in Islam as "based on sensuality and not love" and regarded Muslim wives as "prisoners and slaves rather than companion and helpmeet." ${ }^{, 54}$ Conversely, Ahmed understands modern and universalist understandings of love as "rooted in the colonialist critique of Muslim societies." "55 In a 
Draft $-1^{\text {st }}$ Draft

similar vein, Abu-Lughod critiques modernists' depictions of arranged marriages as lacking "affection and companionability." 56 Through a minute analysis of the work of Qasim Amin, Egypt's quintessential modernist thinker, who argued that Egyptian women were "incapable of truly loving their men," and that Islamic scholars have "reduced marriage to a contract by which a man has the right to sleep with a woman," Abu-Lughod successfully shows how modernists' idealization of "companionate marriage" or love-based marriage became a suitable vehicle for the instrumentalization of gender during the period of nation- building in Egypt. ${ }^{57}$ More recently, Beth Baron conceived love as a bourgeois ideal that bases itself on marriage in 1990's Egypt, ${ }^{58}$ whereas Viola Shafik, ${ }^{59}$ Lila Abu-Lughod, ${ }^{60}$ and Rebecca Joubin $^{61}$ drew respectively on Egyptian cinema, Egyptian television productions, and Syrian ones, in order to show how discourses related to love and sex are mediated through carefullydeveloped scripts that simultaneously uphold and contest larger societal paradigms related to gender, sexuality, and the nation.

\section{LOVE AND AFFECT}

Affectivities, including love, are evoked because they are capable of responding to "relations of power" that "operate through bodies in ways that are both more direct than theories of discourse, ideology, and deliberative reason," in addition to being "more elusive from the perspective of conventional analytic and critical strategies." ${ }^{\text {, }}$ My findings compel me to surrender to love's elusiveness. This surrendering, though, is not akin to a "lost game." On the contrary, it is telling of the spaces and knowledges that are yet to be. As discourse, love is inevitably taught, evident in my interlocutors' views. Throughout my fieldwork, love was repeatedly reiterated not only in relation to materiality but also in conjunction with the Unknown, thus agreeing with Deborah Thien, who states that "love enacted as a politics of 
Draft $-1^{\text {st }}$ Draft

(im)possibility blurs mental and visceral experience, moving us beyond the everyday metaphysics of mind versus body to a more complex and intersubjective reading.,

The Unknown is two-fold. One the one hand, it reiterates my interlocutors' geopolitical anxieties about the region's future, and the feeling that "war is coming.,"64 Lebanon's ruling class' failing strategies, typified by my interlocutors' preoccupation with the intensification of the institutionalisation of sectarianism, and the view that migration is inevitable, largely informed my interlocutors' views and experience of inter-sectarian love. On the other hand, and political materiality aside, the unknown is invoked as destiny, or qadar. Destiny was the culprit in the making and dissolution of love stories. That one's destiny has already been written is a direct reiteration of the elsewhere, and of an existence where both the invisible and the visible collide and contribute to the production of subjectivities. The Unknown is a resignation-acceptance of the limits of knowing; in addition to acting upon the self, it allows the forging of "lines of flight." The interplay between destiny, piety, and individual and collective reflexive practices that permeates my findings echoes the recent "ethical turn" encountered in anthropological endeavours. In addition to drawing our attention to "the fundamental roles of human passions and transcendental powers in shaping people's . . . existential journeys," anthropology's "ethical turn" forces us to reflect on "modalities of agency and (inter)subjectivity" that "rational understanding" falls short of capturing fully. ${ }^{65}$ Accordingly, love coincides with Seigworth and Gregg's understanding of affects as "those visceral forces beneath, alongside, or generally other than conscious knowing, vital forces insisting beyond emotion."

Love comes in a myriad of forms, many of which are "impossible," and it is precisely these momentary stations that I am interested in. In the particular context of post- civil war Lebanon, where national reconciliation is yet to be established seriously, inter-sectarian love, despite its short life, exhumes a particular agency for those men and women involved - one 
Draft $-1^{\text {st }}$ Draft

"against all odds," which attempts, but fails, to reverse the status quo. Conversely, I stress the "spatial, relational, and political" dimensions of love. Morrison et al's reasoning highly befits my findings. I add temporality to their conceptualization in order to strengthen the shifting meaning of affects and their non-disassociation from power structures.

In her critique of Eurocentric interpretations of emotions, Divya Tolia-Kelly reminds us that "affective economies are defined and circulate through and within historical notions of the political, social and cultural capacities of various bodies as signified rather than those specifically encountered, felt, loved, loathed and sensed." ${ }^{67}$ Indeed, and although I view love as an affect, I must be careful in my analysis to not remove it entirely from the Social. ${ }^{68}$ Whereas the volatility of love results in deterritorialzing processes, the Social inevitably grounds it. Following my research, religion, sect, class, and nationality are the essential categories that limit the potentials-intensities of love. The literature increasingly recognizes the transformative potential of affects. In her analysis of love as a political concept, Lauren Berlant states that "a properly transformational political concept would provide the courage to take the leap into a project of better relationality that would give us patience with the "without guarantees' part of love's various temporalities." ${ }^{69}$ This absence of guarantee is not limited to political demands per se. Ruba Salih took the risky task of relating Palestinian women's experiences of and engagement with "love" in refugee camps in order to "displace nationalist affects by opening up other types of affects nested in the concreteness of ordinary relations, attachments and responsibilities." Salih's work speaks directly to my work, particularly where I call for the recognition of the reconciliatory - albeit temporary - potential of inter-sectarian love in contemporary post- civil war Lebanon.

\section{LOVE, MARRIAGE, AND SECT}


Draft $-1^{\text {st }}$ Draft

The intersection of sect with gender in Lebanon, notably personal status laws, has been laregely examined by scholars in order to show how the relocation of matters considered "private" - to name marriage, divorce, child custody and inheritance - to the religious realm reproduces unequal patterns of citizenship, depending on one's sect and gender. ${ }^{70}$ Conversely, the literature on personal status laws in Lebanon offers a nuanced interpretation of the takenas-given notion of patriarchy, since it captures unequal citizenships between and within women and men. There are three religion-groups in Lebanon (Muslim, Christian, and Druze), which are constituted of eighteen recognized sects. In other words, there are eighteen different ways to deal with each of the matters related in the personal status laws. If, like Maya Mikdashi, ${ }^{71}$ we add the category of sex or differentiate between "madhab," and "sect," we are left with an ever-growing number of equations. The relocation of personal laws to the private sphere reinforces the legal and religious architecture of Lebanon's distinct communities, to the extent they acquire an Andersonian meaning:

While it is important to look at the historical specificity of the construction of collectivities, there is no inherent difference between them, whether they are constructed as ethnic, national racial co-religious (although sometimes there is a difference in scale): they are both Andersonian imagined communities. ${ }^{72}$

In addition, their relocation absolves the state from its civic duties. As a result, extended kin have come to act as the "primary location for protection against the state," as Suad Joseph rightly argues. ${ }^{73}$ For those individuals who, for an array of reasons, decide to operate outside of the parameters of personal status laws, they risk being doubly jeopardized. This was the case for those activists who sought to register their (heterosexual) marriage directly with the state; we learn from Mikdashi that they soon "found themselves unable to inherit, run for public office, or register their marriage certificate or their new-born children in the government registries." Although my work is concerned with inter-sectarian love, which does 
Draft $-1^{\text {st }}$ Draft

overlap with but does not equate civil marriage, both share the same element of queerness as political hope.

Love, I pointed out earlier, is relational, political, and social, but is also highly unpredictable and ambivalent, a point that most of the literature on the topic emphasizes. This is why I find it more useful to analyse what love does, rather than what love is in my work. Where sect is concerned, courtship periods reveal minute processes of negotiations particularly where politico-sectarian allegiance arises, including in the context of intrasectarian couples. Marriage, unlike love, territorializes, and reproduces Lebanon's religious/political nexus.

Inter-sectarian love was mostly remembered by my interlocutors. In addition to constituting a "headache," it emerged as a losing game. For many, and I draw form Gloria Anzaldúa here, inter-sectarian love is akin to a space where one simultaneously "feels alienated from one's original culture and yet alien in the dominant culture." ${ }^{, 74}$ Following my empirical work, love is sought and experienced outside of, and in juxtaposition to marriage. This is not to say that the marital unions I encountered are devoid of love. On the contrary, my interlocutors described their relationships as based on "love" and "personal choice." In addition, they pointed out the importance of "insijam," a particular affect that has been examined at length by Adely in the context of Jordan. ${ }^{75}$ Insijam, which I translate as "synchronicity," is defined by Adely as "a level or type of compatibility that would ensure marital stability, prevent discord among families and, potentially, foster love between husband and wife." ${ }^{, 76}$ In Adely's work, insijam is constructed as the responsible and ideal type of love, since it is capable of encompassing both the couple's compatibility with each other, and their kin approval. Similarly, most of interlocutors considered intra-sectarian lovemarriage, or love that is geared towards marriage as the "right" kind of love. Lubna, for instance, was one of the few interlocutors who vehemently opposed inter-sectarian liaisons. 
Draft $-1^{\text {st }}$ Draft

According to her, it is "very important to be careful whom one dates these days because times are difficult.",77 Following Lubna, "respect is more important, and if you have your family's and your husband's support, then you needn't worry about anything.,"78

Lubna's views are pragmatic and resonate highly with the words of Izza, who, referring to the scope and influence of kin and communal ties, observe that "to marry a man is to marry his entire family." 79 Izza informed me that she would get married to "anyone, as long as he is Shi'a like [her]. ${ }^{\prime 80}$ When I enquired why she distinguishes between the Sunni and the Shi'a branches of Islam, she asked me whether I "could you imagine a supporter of Hezbollah (Shi'a political party) living side by side with a Hariri (Sunni political party) supporter." ${ }^{\circ 1}$ When I answered with a yes, she scolded me by asking me to "get real" and to "not act smart," before adding that "it might taste like honey in the beginning, but everything will turn sour soon." $" 82$

My findings suggest that whereas pre- marriage adulthood abound with inter-sectarian love affairs, one reverts to strictly intra-sectarian connectivity at the time of marriage. It is the temporality of inter-sectarian love that rouses my curiosity mostly. Before entering university, Nūr's parents insisted that she wears the veil. Although Nūr ignored her parents' request at first, she eventually started veiling once they threatened to stop paying her university fees. Nūr's parents, like many parents, are aware that university, often times, is young people's first interaction with the "outside world." For many students, university allows them to interact closely with people from other sects. By insisting that Nūr wears the veil, her parents were hoping that she will not "drift" and that the veil, as a signifier, will help constrict her friendships to equally "pious" and "God-fearing students," a reality that Nūr relates in a highly sarcastic tone. ${ }^{83}$

It is important to nuance the views of Nūr, Lubna, and Izza. For the untrained eye, each could be mistaken for a puritan who purposefully draws binaries between her community 
Draft $-1^{\text {st }}$ Draft

and any other, as a righteous community member who exclude specific "others," or as a fundamentalist who is strictly motivated by politico-sectarian beliefs. However, the reality is way more complex, and I identity two important factors. On the one hand, the enmeshment of relationality with politico-sectarian allegiance in Lebanon reproduces strict patterns of sociability that trump individual desire and privilege communal ties. One the other hand, it is important that we deconstruct sectarian belonging by stressing the intersection of sect with class and economic precarity.

Suad Joseph conceptualizes the enmeshment of kin relations with the apparatus of the state, including political affiliation as is the case with Izza, through what she terms "care/control paradigm" whereby men care (love) and control (power) women. ${ }^{84}$ The intersection of relationality with a patriarchal order results in an affective paradox in Lebanon: love becomes entangled with power. According to Suad Joseph, the Lebanese self emerges from and reproduces what she terms "patriarchal connectivity." This self recognizes itself as "extended," since it sees itself as part of "significant others." 85 At the same time, this connectivity is informed by politico-sectarian bonds and deeply-rooted patriarchal underpinnings, to name the privileging of the males and the elders over women and the youth. ${ }^{86}$ Where seemingly puritan sectarian reinforcement is concerned, I draw directly on Nadine M. who rightly reminds us that:

In the particular case of Lebanon, religion becomes fundamentalist when several factors take their toll on a community, such as poverty, a negligent or corrupt state, sectarian feuds and wars, and a general socio-economic inability to adjust to this post-modern, globalized world. Religion thus intervenes and becomes more political, speaking out against what it perceives as the threat of secularism and providing services for impoverished communities that the state has long neglected. And so, fundamentalism rises and takes on a sectarian face. ${ }^{87}$ 
Draft $-1^{\text {st }}$ Draft

Still, Nadine M.'s analysis is not in absolute. Lubna, for instance, comes from a "good family" and a wealthy one. A good family is not necessarily measured in terms of wealth; rather, it is indicative of a family that upkeeps good morals and values, or akhlāq, in addition to evoking the importance of having ancestry that can be traced. ${ }^{88}$ In such cases, convenience marriages, politics of respectability, and one's family's social and political influence all intervene towards the production of particular affective pedagogies. Economic and social capitals aside, emotional capital plays an important role in the affective pedagogies of my interlocutors. Emotional capital is not necessarily measurable. For many of my interlocutors, the surplus of passion is constantly contrasted with their families' expectations. Several interlocutors insisted me their parents' religious views are not fundamentalist, but it would "break their parents' heart" if they married outside of their sect.

The conflictive affectivities that define my interlocutors' narratives are telling of the spatial, relational, and political dimensions of romantic love in Lebanon: inter-sectarian love is an impossible affect that can only be experienced outside the socio-political boundaries of one's community. In addition, it is rarely lived in the present. It is repudiated in the present, remembered in past terms, and longed for. As Jana noted, "it [the materialization of material unions based on inter-sectarian love] is too late for my generation, but who knows what the future holds?" 89

\section{THE TEMPORALITY (AND SPATIALITY) OF LOVE}

Jana, like many of my interlocutors, shared with me her past love affairs, including two intersectarian liaisons. Jana's testimonies were highly sensorial. Like many of the men and women I spoke to, she enthusiastically related excursions to "novel" geographical locations, foods she "had not tried before," "new music genres," and "embarrassing moments." 90 When Jana met Ahmed during her second BT year, ${ }^{91}$ it was, according to her "love at first sight." 92 Jana, an 
Draft $-1^{\text {st }}$ Draft

Orthodox Christian from Beirut, had "little in common" with Ahmed, a Sunni Muslim from the region of Akkār, but "something kept drawing them to each other." 93 Following Jana, Akkār was an "off-limit" region. ${ }^{94}$ Like many parents, including mine, Jana belongs to a generation of overly cautious parents, who navigate present Lebanon alongside memories of trauma, death, and doubt. Lebanon's distinct sectarian communities inhabit more or less fixed geographical locations, with the exception of larger cities. ${ }^{95}$ For its post- civil war youth, including my interlocutors, they are more likely to travel abroad than visit new locations in Lebanon. ${ }^{96}$ Jana remarked that, "when Ahmed took me to Akkār, I was speechless! I had no idea! My idea of Akkār is that it is underdeveloped ... Yes, I could see high levels of poverty, but the landscape was phenomenal! No one tells you about it!"97

For several of the interlocutors I spoke to, space constituted an important element of their reminiscent exercise. Oftentimes, the specific locations they relate acquire a "liminal" meaning, a "threshold" between two worlds, so to speak." 98 For Jana, her visits to Akkār constitute a threshold in her post- civil war Lebanon existence. At the same time, Akkār embodies a past that is both "painful" and "worth it." 99 It is painful because "it brings forth memories of her love for Ahmed," and worth it because "it opened up her eyes to the diversity of Lebanon." 100 At the time of my fieldwork, Jana was preparing to wed Dany, an Orthodox Christian, like her. When I interviewed her alone on our third meeting, she told me that she asked Dany to visit Akkār the coming Sunday for their weekly excursion: "He could not comprehend my insistence on visiting Akkār, but I genuinely miss it."101 I asked Jana, "Are you in love with Ahmed still?"102 She replied with an assertive "No. Of course not! I am about to get married. I have no time for romance now." "103 Jana's statement relegates her sentiments for Ahmed to the realm of the past, in addition to distancing them from the affective meaning she ascribes to marriage. Conversely, it helps that we view the institution of marriage in Lebanon as a strictly "chrono-normative" practice that "uses time and organizes 
Draft $-1^{\text {st }}$ Draft

individual human bodies toward maximum productivity," in addition to making people "feel coherently collective, through particular orchestrations of time." 104

For many of my interlocutors, marriage, is binding in the relational sense. Lara distinguishes it from romance by highlighting the latter's "selfishness."105 Following Lara, “it's easy to romanticize things and to go against the current when you're younger, until you realize how high the stakes are." ${ }^{106}$ Indeed, the stakes are high for those who insist on pursuing a particular love in spite of kin disapproval. Throughout my fieldwork, kin's reaction to no-approved unions ranged from disownment and disinheritance, to complete rupture. Still, it would erroneous to blame kin's interference for the dissolution of inter-sectarian love. Most of my interlocutors decided to "uncouple" from their partners themselves, and many jokingly qualified inter-sectarian love as a "headache." When I met Jomana, a Sunni Muslim, towards the end of 2014, she was becoming increasingly disillusioned with her love for Eli, a Christian Maronite. On one particular afternoon, she remarked:

I don't know where this is going. After the evening prayer yesterday, I broke down and cried for hours. I was thinking to myself. What am I doing? How could I think that my relationship with Eli could go anywhere? It will never happen. It will break my mother's heart. ${ }^{107}$

Like many of the interlocutors I spoke to, Jomana found herself torn between her feeling for Eli, and her parents' reaction. Similar feelings of guilt were raised by Mireille, who grew considerably angry with her friends following her break up with Gowda: "I hated everyone back then, especially my friends. How could they not have stopped me?"108 By blaming her friends, Mireille is projecting her agency onto them. To some extent, she exhibits a connective type of agency whereby one's agency is channeled through others. By willingly submitting herself to her friends' dictations, she finds a moral reference in them. In the context of Lebanon, one's agency, like most notions, practices, institutions, whether formal or not, operates through Suad Joseph's concept of "patriarchal connectivity." 
Draft $-1^{\text {st }}$ Draft

Still, and despite the dilemmas that riddle their everyday, one must not make assumptions about Mireille and Jomana's love life. For Mireille, she was adamant that she would never date someone from a different sect again because she "couldn't possibly cope with the magnitude of the headache" ${ }^{\prime 109}$ she had previously experienced. Equally, when I contacted Jomana to follow up on her relationship with Eli in 2015, she told me they both decided to "uncouple." Her mother had introduced her to a distant relative whom she agreed to marry. When I asked Jomana what memories she will keep from her relationship with Eli, she fondly remembered Eli's mother's food dishes, particularly "her kibbeh nayyih," before stating the inevitable "waja' $r \bar{a} s$ " or headache. ${ }^{110}$

Not all the inter-sectarian love stories I encountered were faced by hostile kin reactions. On the contrary, my fieldwork compels me to push for an either/and understanding of kin relations in the context of romantic love in Lebanon, since many of my interlocutors relied on the emotional labor of friends and kin members for the legitimation of their love in the eyes of their immediate family. Such instances are best viewed as interruptions in Lebanon's normative timeline. Here, personal freedom emerged alongside disillusionment with Lebanon's politico-sectarian governance. Whereas my interlocutors use the expression of headache figuratively, I draw on their malaise to formulate "lebanese-ness," a two-fold imagined condition of ill-living where the present is lived "on hold" seeing the "inevitability of migrating sooner or later," and where protests and demands converge. Aline, whose feelings for Diya re-ignited during our conversation, told me that she was "beyond fed up with everything in this country," and that she was eagerly awaiting her student visa for a Master's degree in France. ${ }^{111}$

Lebanese-ness is attuned to agency, subjectivity, and to the everyday, in addition to escaping the notions of nationalism, sovereignty, patriotism, and the like. It operates in and between the individual, the communal, and the plural, and thus encompasses the intimate, the 
Draft $-1^{\text {st }}$ Draft

private, the public, the national, the cosmopolitan, and the global. Lebanese-ness is the convergence of both protests and demands in a single locus in contemporary Lebanon, an "undetermined context" so to speak. What one desires (Lebanon) is the very object that contributes to one's ill-living (Lebanon). Lebanese-ness brings forth the concept of the “elsewhere," as posited by Donna Haraway:

'We', in these discursive worlds, have routes to connection other than through the radical dismembering and dis-placing of our names and our bodies. We have no choice but to move through a harrowed and harrowing artifactualism to elsewhere."112

Easily put, the "elsewhere" is never entirely knowable. It is an imaginary leap of faith that we take, and which propels us into a world of novel possibilities. The "elsewhere" was highly visible during my fieldwork, evident in my interlocutors consistent contrasting of the myriad of failure(s) that inform their everyday, with barra (abroad), understood as "anywhere but here." When I asked K. whether the fact that the "love of his life" had recently been naturalized in Australia made "falling in love" with her "easier," he calmly replied that "I was not mistaken," and that "everyone else is doing it."113 The geographies of love equally figure in Clara's remarks:

Some people convert for the sake of getting married. This is wrong! We should all refrain from getting married until civil marriage is permitted in Lebanon. Not everyone can afford the trip to Cyprus, you know? Also, some of us are more sensitive than others. It is absolutely out of the question for me to convert to something else, even if it was simply in ink form. It would break my mother's heart! ${ }^{114}$

There exist today Lebanese and Cypriot businesses that specialize in arranging travels to Cyprus for Lebanese nationals who wish to marry civilly. While the Lebanese state does not itself conduct civil marriages, it does recognize those obtained elsewhere. Here, the element of class is crucial, as Clara points out. At the same time, her narrative reflects the limits of class, seeing the affective concerns she raises vis-à-vis conversions. The literature on civil marriage in Lebanon is steadily gaining ground, and its critical tone resonates throughout its 
Draft $-1^{\text {st }}$ Draft

examination of the gendered and racialized characters of the institution of marriage in Lebanon. In what follows, I draw on the case of civil marriage activists in Lebanon, in order to conceive love as a queer affect, seeing its potential to destabilizing institutionalized sectarianism.

\section{ROMANTIC LOVE AS POLITICAL HOPE}

Mikdashi's "queer" reading of Lebanese citizenship is undoubtedly puzzling to western liberals' formulation of citizenship: the entanglement of personal status laws with further practices related to citizenship in the context of state-backed strategic conversions allow Lebanese citizens to (almost) personalize their relationship to both state and society, a quite unfathomable paradigm in the realm of the "universal citizen," where the personal is deliberately downgraded for the sake of the linear state. In many ways, Mikdashi's metatheory of queering citizenship is one example of a "theory from the South." ${ }^{\prime 15}$ It is an alternative model of thinking that privileges intersectional analysis when thinking through citizenship and exploring the space between citizen and state, in addition to widening our understanding of what constitutes democratic citizenship and participation in the first place. Mikdashi is not the first to critique the "reification of the global south as raw data" to be queried. ${ }^{116}$ A number of scholars have explored the space in-between the Metropole and its colonies through a queer lens for purposes ranging from "undermining the authenticity of the dominant order"117 to reclaiming local onto-epistemologies. ${ }^{118}$

In another work, Mikdashi highlights the limits of "civil marriage" activism in Lebanon. Whereas civil marriage activists are partly driven by ideals to reformulate civil participation vis-à-vis the state on the whole, they coincide with my interlocutors' feelings of loss. The classed and affective dimensions of civil marriage to which I pointed out earlier is at best a "compromise" between the state and those involved in that it does not directly 
Draft $-1^{\text {st }}$ Draft

challenge the personal status laws, Lebanon's deeply-rooted religious/political nexus. Love as a feeling that is pure and elective is constructed as unattainable in Lebanon. This is evident in the gap between the lived reality of my interlocutors on the one hand, and the success of "impossible love stories" in the love registers that Lebanese citizens draw on, including locally-produced TV series, movies, love songs or novel, on the other hand.

Feminist researchers in the Middle East have no choice but to engage empirically with their object of research, including where affects are concerned. If anything, they are expected to, and they do, re-examine gender in an increasingly militarized climate. This reality means that few works engage with the Middle East from affective perspectives. The intensification of violence and the rise of the military, warranted by neo-authoritarian states, mean that a new generation of activists are forging new spaces for themselves in order to make themselves heard. Among these spaces, I name pleasure, leisure, music, love, and so on. Such spaces are not simply spaces for consumption. They are the spaces that allow new generation of men and women to express and reclaim their "right to the city," 119 their right to love, and their right to exist. Their affective lives examine us to investigate the contemporary Middle East from an onto-epistemological perspective where the examination of emotions is central - not secondary. Also, their understanding of liberation is not a conventional one. Liberation, in their case, is not a physical state where security, borders, or geopolitics are at stake. If anything, their liberation, and I stress here, is a mental and affective one - a wilful exercise of the sort, a reflexive pedagogy where they re-write the violent history that constituted their everyday, from their early childhood to adulthood.

Recent works have successfully showed the political scope of emotions and its impact on the researcher, her interlocutors, and the field. In their special issue on ethnographic research in the Middle East in Contemporary Levant, the authors proceed their analysis from an emotive point of departure, and rightly so. ${ }^{120}$ In the same vein, Sertaç Sehlikoglu invites us 
Draft $-1^{\text {st }}$ Draft

stop ignoring the "multiplicity of women's (and men's) subjectification, which inevitably embraces realms of aspiration, desire, and enjoyment." ${ }^{, 21 \square}$ Similarly, Ruba Salih critiques the modern moral discourse that "dislodges" the affective potentials of the body from the public sphere. Instead, Salih recognizes the emotional capital that constitutes her interlocutors' "everyday." 122 By doing so, she successfully closes the gap between the erroneous perception of the everyday as apolitical on the one hand, and what counts as properly "political," on the other hand. What counts as "properly political" is not limited to discursive interpretations and lengthy detached analysis. Rather, it is found in passing glimpses, reminiscent narratives, remnant memories, and imaginative landscapes. They are "ephemeras" that serve as "visible evidence." ${ }^{\prime 23}$ Drawing on queer livelihoods, Muñoz's configuration of the queer other as vulnerable highly befits my interlocutors' inter-sectarian love experience:

Queerness is often transmitted covertly. This has everything to do with the fact that leaving too much of a trace has often mean that the queer subject has left herself open for attack. ${ }^{124}$

I argued in this paper that the short-liveness of inter-sectarian love is best analysed through an affective lens. Far from defining love, I focused on what love does. Love is "relational" "spatial" and "political.".125 It is relational because it creates novel affectivities that transcend the boundaries of one's sectarian community. It is spatial because it is embodied. It is political because it speaks directly to the lived reality of young men and women in post- civil war Lebanon: with the privileging of neoliberal reconstruction projects at the expanse of national reconciliation, inter-sectarian love is a credible arena for understanding the entanglement of agency with the larger apparatus of power in Lebanon, in addition to assisting us move our analysis beyond the "sectarian deadlock" that permeates uncritical works on Lebanon.

Whereas the topic of love seems "trivial" compared to the imminent implications of the Global War of Terror, I recommend that we approach the topic whilst appreciating its agentic potential. Seeing its potential of destabilizing normative intra-sectarian connectivity 
Draft $-1^{\text {st }}$ Draft

and its projection towards "impossible" others, this paper views heterosexual love as a queer affect. Here, queer is invoked as political hope, a "futurity" that is yet to be, following the work of the late José Muñoz, ${ }^{126}$ and the "better story"127 to be told:

Queerness is an ideality. Put another way, we are not yet queer. We may never touch queerness, but we can feel is as the warm illumination of a horizon imbued with potentiality. We have never been queer, yet queerness exists for us as an ideality. ${ }^{128}$

Muñoz draws on the works of Lee Edelman (2004) in order to complicate his notion of "the future as kid stuff," a metaphor that emphasises the figure of the child, rather than the queer, as the anticipated guardian of heteronormative and homonormative values. The child, in this sense, is akin to a floating sign to which all knowledges are referred. In contrast, the queer deviates from the stability offered by the child. They are the anti-thesis of the child. Not only do they destabilize compulsory heterosexuality, they are capable of absorbing the surplus that confuses the child, which leads it to its disavowing, rejection, and marginalization. The "fascism of the baby's face," as Edelman calls it, or the reproduction of the future as iteration of the same is reflective of an artificial utopia from which dissidence is forcefully removed. Muñoz's configuration of queerness as a utopia that is yet to be succinctly captures my interlocutors' affective dilemmas: they are caught between the imperative of intra-sectarian marriage and the unattainability of inter-sectarian love. As a result, my queering of heterosexual love does not "refer" it "back to US queer studies," 129 because it works within a localized understanding of time, which promptly answers Mikdashi's call to queer Middle Eastern studies.

Last but not least, it is important to include in my queering of heterosexual love what Lila Abu-Lughod calls the "romance of resistance," or reading "all forms of resistance as signs of the ineffectiveness of systems of power and of the resilience and creativity of the human spirit in its refusal to be dominated." ${ }^{130}$ Following Abu-Lughod's work on the Bedouin 
Draft $-1^{\text {st }}$ Draft

setting of the Awlad 'Ali tribe in Egypt, love poetry, which could be interpreted as a frivolous pastime by some, becomes the vehicle through which generational conflicts related to tradition and modernity, notably young men's defiant views on forced marriage, are channeled. ${ }^{131}$ We learn from Abu-Lughod that the tradition of Bedouin love poetry is concomitant with and dependent on the very agnatic, patriarchal and patrilineal authorities that deny it in the first place, and that it would be futile to view them as resistance per se. Instead, we are presented with a study that convincingly demonstrates that emotions do not emanate from a free-floating inner self; rather, emotions ought not to be thought of in disassociation from their cultural context. ${ }^{132}$

Abu-Lughod's advice is important. After all, it is my analysis, as a researcher, that bestows on inter-sectarian love the potential to affect social transformation. Such reflections bring forth recent ethnographic work by Laleh Khalili where she examined the "pleasures," notably the activities of promenading and beachgoing, of young Palestinian women from refugee camps in Beirut. ${ }^{133}$ Mindful of her privileged position as researcher, Khalili reads beyond her interlocutors' narratives. She carefully unpacks the power configurations underpinning said narratives in her reading of pleasure and stops short of referring to promenading and beachgoing as resistance. Instead, she recommends that we view such activities as "moments of pleasure," or "caesuras in the massive apparatus of power - welded from strands of wage labor, nationalist certitudes and political exclusion - which constricts these women." ${ }^{\text {134 }}$ Equally, I avoid romanticizing inter-sectarian love in my work. Whereas I acknowledge the validity of emotions as credible and objective sources of knowledge, I stop at recognizing their potential to affect change. This is a consciousness step that avoids speaking on behalf of the lived experience of my interlocutors whilst recognizing agency as that "capacity for actions that historically specific relations of subordination enable and create."135 
Draft $-1^{\text {st }}$ Draft

\section{NOTES}

Acknowledgements to be included.

${ }^{1}$ The names of all my interlocutors have been changed in order to guarantee their anonymity. The names I choose are random and do not necessarily reflect one's sect. In addition, some nicknames, chosen by my interlocutors themselves, were used in lieu of common names, as per their request.

${ }^{2}$ Khutūbah is the step that precedes marriage in Lebanon. Khutūbah marks the event from which the couple emerges as "official" in the eyes of society. It is not religiously sanctioned and is not necessarily an indication that marriage is imminent.

${ }^{3}$ Aline, interview with the author, February 2014, Tripoli.

${ }^{4}$ In their examination of leisurely activities among Shi'a youth in southern Beirut, Deeb and Harb (2013) show how their young interlocutors reconcile between their religion, their attachments to the political party of Hizbollah, and leisurely activities. See Lara Deeb and Mona Harb, Leisurely Islam: Negotiating Geography and Morality in Shi'ite South Beirut (Princeton: Princeton University Press, 2013).

${ }^{5}$ Aline, interview with the author, February 2014, Tripoli.

${ }^{6}$ Ibid.

${ }^{7}$ Maya Mikdashi, “Queering Citizenship, Queering Middle East Studies," International Journal of Middle East Studies no. 45 (2013): 350.

${ }^{8}$ Ibid.

${ }^{9}$ Ibid. 
Draft $-1^{\text {st }}$ Draft

${ }^{10}$ Maya Mikdashi, "Sex and Sectarianism: The Legal Architecture of Lebanese Citizenship," Comparative Studies of South Asia, Africa, and the Middle East vol. 34, no. 2 (2014): 279293

${ }^{11}$ Ibid., 281.

12 Ibid., 283.

${ }^{13}$ Ibid.

${ }^{14}$ Similar paradigms are raised in critical investigations of homosexual desire. See Dennis Altman, Global Sex (Chicago: Chicago Unviersity Press, 2002); and Lisa Duggan, “The New Homonormativity: The Sexual Politics of Neoliberalism," in Materializing Democracy: Toward a Revitalized Cultural Politics, ed. Russ Castronovo and Dana N. Nelson (Durham and London: Duke University Press, 2002), 175-194.

${ }^{15}$ Mark B. Padilla, Jennifer S. Hirsch, Miguel Muñoz-Laboy, Robert Sember, and Richard G. Parker, Love and Globalization: Transformation of Intimacy in the Contemporary World (Nashville: Vanderbilt University, 2008), ix.

${ }^{16}$ Lauren Berlant and Michael Warner, "Sex in Public," Critical Inquiry, vol. 24, no. 2 (1998): 547-566.

${ }^{17}$ Lee Edelman, No Future: Queer Theory and the Death Drive (Durham: Duke University Press, 2004).

${ }^{18}$ bell hooks, All about Love: New Visions (New York: William Morrow, 2000).

${ }^{19}$ Duggan, The New Homonormativity: The Sexual Politics of Neoliberalism, 175-194.

${ }^{20}$ Elizabeth Freeman, Time Binds: Queer Temporalities, Queer Histories (Durham: Duke University Press, 2010).

${ }^{21}$ My interlocutors' age ranged between twenty-nine and thirty-four. With the exception of four women, all had pursued further education upon graduating from high school (either by following a vocational pathway or pursuing higher education) and were working or actively 
Draft $-1^{\text {st }}$ Draft

looking for work at the time of my research. Also, and although my interlocutors come from a middle-class background, it is important to view their middle-class along a spectrum of precarity, and to recognize the imprecision of class categories.

22 Gloria Anzaldúa, Borderlands/La Frontera: The New Mestiza (San Francisco: Spinsters/Aunt Lutte, 1987), 3.

${ }^{23}$ Gayatri Gopinath, Impossible Desires: Queer Diasporas and South Asia Public Cultures (Durham: Duke University Press, 2005).

${ }^{24}$ José Muñoz, Cruising Utopia: The Then and There of Queer Futurity (New York: New York University Press, 2009).

${ }^{25}$ Ibid., 1.

${ }^{26}$ Carey-Ann Morrison, Lynda Johnston, and Robyn Longhurst, "Critical Geographies of Love as Spatial, Relaional and Political," Progress in Human Geography vol. 37, no. 4 (2012): 505-521.

27 Maya Mikdashi, “Queering Citizenship, Queering Middle East Studies,” International Journal of Middle East Studies no. 45 (2013): 350-352, 350.

${ }^{28}$ See Ruba Salih, "Bodies that Walk, Bodies that Talk, Bodies that Love," Antipode: A Radical Journal of Geography vol. 49, no. 3 (2016): 742-760; Dina Georgis, The Better Story: Queer Affects from the Middle East (New York: SUNY Press, 2013); Hanadi AlSamman and Tarik El-Ariss, "Queer Affects: Introduction," International Journal of Middle East Studies vol. 45, no. 2 (2013): 205-209.

${ }^{29}$ Morrison et al, Critical Geographies of Love as Spatial, Relaional and Political, 507.

${ }^{30}$ Sally Munt, "Sisters in Exile: The Lesbian Nation," in New Frontiers of Space, Bodies and Gender, ed. Rosa Ainley (London: Routledge, 1998), 3-19.

${ }^{31}$ Padilla et al, Love and Globalization, ix. 
Draft $-1^{\text {st }}$ Draft

${ }^{32}$ Barbara S. Mensch, Susheela Singh, and John B. Casterline, "Trends in the Timing of First Marriage among Men and Women in the Developing World, in The Changing Transitions to Adulthood in Developing Countries: Selected Studies, eds. Cynthia B. Lloyd, J. R. Behrman, N. P. Stromquist, and B. Cohen (Washington, DC: National Academies Press, 2005), 118171.

${ }^{33}$ For an extended literature review on the notion of love, see Begonya Enguix and Jordi Roca, "Introduction," in Rethinking Romanic Love: Discussions, Imaginaries, and Practices (Newcastle Upon Tyne: Cambridge Scholars Publishing, 2005), 1-28.

${ }^{34}$ Charles Lindholm, "Romantic Love and Anthropology," Etnofoor vol. 19, no. 1 (2006): 521; Jonathan Gottschall and Marcus Nordlund, "Romantic Love: A Literary Universal?" Philosophy and Literature, vol. 30, no. 3 (2006): 450-470; William Jankowiac, Love and Sex Across Cultures (New York: Columbia University Press, 2008); Sara Pinto, "Researching Romantic Love," Rethinking History: Journal of Theory and Practice vol. 21, no. 4 (2017): $567-585$.

${ }^{35}$ Begonya Enguix and Jordi Roca, Rethinking Romanic Love: Discussions, Imaginaries, and Practices (Newcastle Upon Tyne: Cambridge Scholars Publishing, 2005), 1.

${ }^{36}$ Corinne Fortier, Aymon Kriel and Irene Maffi, "The Trouble of Love in the Arab World: Romance, Marriage, and the Shaping of Intimate Lives," Arab Studies Journal vol. 24, no. 2 (2016): 96-101.

${ }^{37}$ Carole S. Vance, "Pleasure and Danger: Toward a Politics of Sexuality," in Pleasure and Danger: Exploring Female Sexuality, ed. Carole S. Vance (Boston: Routledge \& Kegan Paul, 1984): $1-28,1$.

${ }^{38}$ Carole S. Vance, "Social Construction Theory and Sexuality," in Constructing Masculinity, ed. Maurice Berger, B. Wallis, and S. Watson (New York: Routledge, 1995): 37-48, 41. 
Draft $-1^{\text {st }}$ Draft

${ }^{39}$ Illouz, Eva, Consuming the Romantic Utopia: Love and the Cultural Contradictions of Capitalism (Berkely: University of California Press, 1997).

${ }^{40}$ Perveez Mody, The Intimate State: Love-Marriage and the Law in Delhi (London, New York and New Delhi: Routledge, 2008).

${ }^{41}$ Jean-Paul Baldacchino, "Eros and Modernity: Convulsions of the Heart in Modern Korea," Asia Studies Review vol. 32 (2008): 99-122.

${ }^{42}$ Xiaowei Zang and Luci Xia Zhao, Handbook on the Family and Marriage in China, Cheltenham, UK: Edward Elgar Publishing, 2017).

${ }^{43}$ Fida Adely, "A Different Kind of Love: Compatibility (Insijam) and Marriage in Jordan," Arab Studies Journal vol. 24, no. 2 (2016):102-127; Sandra Naseer El-Dine, "Love, Materiality, and Masculinity in Jordan: Doing Romance with Limited Resources," Men and Masculinities vol. 21, no. 3 (2018): 423-442.

${ }^{44}$ Samuli Schielkle, Egypt in the Future Tense: Hope, Frustration, and Ambivalence before and after 2011 (Bloomington, IN: Indiana University Press, 2015); Aymon Kreil, “The Price of Love: Valentine's Day in Egypt and Its Enemies," Arab Studies Journal vol. 24, no. 2 (2016):128-146.

${ }^{45}$ Laura Menin, "The Impasse of Modernity: Personal Agency, Divine Destiny, and the Unpredictability of Intimate Relationships in Morocco," Journal of the Royal Anthropological Institute vol. 21, no. 4 (2015): 892-910.

${ }^{46}$ Homa Hoodfar, Between Marriage and the Market: Intimate Politics and Survival in Cairo (Berkeley, CA: University of California Press, 1997).

47 Diane Singerman, Avenues of Participation: Family, Politics, and Networks in Urban Quarters of Cairo (Princeton: Princeton University Press, 1995).

48 Frances Hasso, Consuming Desires: Family Crisis and the State in the Middle East (Stanford: Stanford University Press, 2011). 
Draft $-1^{\text {st }}$ Draft

${ }^{49}$ Charu Gupta, "Hindu Women, Muslim Men: Love Jihad and Conversions," Economic and Political Weekly vol. 13, no. 51 (2009): 13-15.

${ }^{50}$ Rania Maktabi, “The Lebanese Census of 1932 Revisited. Who Are the Lebanese?” British Journal of Middle Eastern Studies vol. 26, no. 2 (1999): 219-241, 226-228.

${ }^{51}$ Mary Deeb, A. Premkumar, S. Karma, S. Akhtar, and L. Messersmith, "Sectarianism and the Problem of Overpopulation: Political Representations of Reproduction in Two LowIncome Neighbourhoods of Beirut, Lebanon" Culture, Health \& Sexuality vol.14, no.10 (2012):1139-1152.

${ }^{52}$ See Patricia Clough, The Affective Turn: Theorizing the Social (Durham: Duke University Press, 2007).

53 Afsaneh Najmabadi, "Crafting an Educated Housewife in Iran," in Remaking Women: Feminism and Modernity in the Middle East, ed. Lila Abu-Lughod (Princeton: Princeton University Press, 1998): 91-125; Women with Mustaches and Men Without Beards: Gender and Sexual Anxieties of Iranian Modernity, (Berkeley: University of California Press, 2005).

${ }^{54}$ Leila Ahmed, Women and Gender in Islam: Historical Roots of a Modern Debate (New Haven: Yale University Press, 1992), 157.

${ }^{55}$ Ibid.

${ }^{56}$ Lila Abu-Lughod, "Introduction," in Remaking Women: Feminism and Modernity in the Middle East, ed. Lila Abu-Lughod (Princeton: Princeton University Press, 1998), 11. (AbuLughod, 1998), 11.

57 Lila Abu-Lughod, "The Marriage of Feminism and Islamism in Egypt: Selective Repudiation as a Dynamic of Postcolonial Cultural Politics," in Remaking Women: Feminism and Modernity in the Middle East, ed. Lila Abu-Lughod (Princeton: Princeton University Press, 1998), 257. 
Draft $-1^{\text {st }}$ Draft

${ }^{58}$ Beth Baron, "The Making and Breaking of Marital Bonds in Modern Egypt," in Women in Middle Eastern History: Shifting Boundaries in Sex and Gender, eds. Nikkie Keddie, and Beth Baron (New Haven: Yale University Press, 1993): 275-291.

59 Viola Shafik, Popular Egyptian Cinema: Gender, Class, and the Nation (Cairo: The American University of Cairo Press, 2007).

${ }^{60}$ Lila Abu-Lughod, Dramas of Nationhood: The Politics of Television in Egypt (Chicago: The Chicago University Press, 2008).

61 Rebecca Joubin, The Politics of Love: Sexuality, Gender, and Marriage in Syrian Television Drama (Plymouth: Lexington Books, 2013).

62 Steve Garlick, The Nature of Masculinity: Critical Theory, New Materialisms, and Technologies of Embodiment (Vancouver and Toronto: University of British Columbia Press, 2016), 48 .

${ }^{63}$ Deborah Thien, “Love's Travels and Traces: The 'Impossible' Politics of Luce Irigaray," Gender and Feminist Geographies Research Group, accessed 16 September 2018, http://www.gfgrg.org/wp-content/uploads/2010/08/Thien.pdf.

64 Sami Hermez, War is Coming: Between Past and Future Violence in Lebanon (Philadelphia: University of Pennsylvenia Press, 2017).

${ }^{65}$ Menin, 894.

${ }^{66}$ Gregory J. Seigworth and Melissa Gregg, "An Inventory of Shimmers," in The Affect Theory Reader (Durham and London: Duke University Press, 2010), 1-25, 3.

${ }^{67}$ Cited in Morrison et al, 515.

${ }^{68}$ Clare Hemmings, "Invoking Affect: Cultural Theory and the Ontological Turn," Cultural Studies vol. 19, no. 5 (2005): 548-567.

${ }^{69}$ Lauren Berlant, “A Properly Political Concept of Love: Three Approaches in Ten Pages," Cultural Anthropology vol. 26, no.4 (2011): 683-691. 
Draft $-1^{\text {st }}$ Draft

${ }^{70}$ Hala Maksoud, "The Case of Lebanon," in Arab Women: Between Defiance and Restraint , ed. Suha Sabbagh, (New York: Olive Branch Press, 1996): 89-93; Suad Joseph, "The Public/Private: The Imagined Boundary in the Imagined Nation/State/Community: The Lebanese Case," Feminist Review vol. 57 (1997): 73-92; Lina Khatib, “Gender, Citizenship and Political Agency in Lebanon," British Journal of Middle Eastern Studies vol. 35, no. 3 (2008): 437-451.

${ }^{71}$ Mikdashi, The Legal Architecture of Lebanese Citizenship.

${ }^{72}$ Nura Yuval-Davis, "Nationalism and Racism," Cahiers de Recherche Sociologique vol. 20 (1993): 183-202, 186.

73 Suad Joseph, "Civic Myths, Citizenship, and Gender in Lebanon," in Gender and Citizenship in the Middle East, ed. Suad Joseph (Syracuse: Syracuse University Press, 2000): 107-136.

${ }^{74}$ Anzaldúa, Borederland/La Frontera, 42.

${ }^{75}$ Adely, A Different Kind of Love.

${ }^{76}$ Ibid, 104.

${ }^{77}$ Lubna, interview with the author, March 2014, Jbeil.

${ }^{78}$ Ibid.

${ }^{79}$ Izza, interview with the author, July 2014, Beirut.

${ }^{80}$ Ibid.

${ }^{81}$ Ibid.

${ }^{82}$ Ibid.

${ }^{83}$ Nūr, interview with the author, September 2014, Beirut.

84 Suad Joseph, "Civic Myths, Citizenship, and Gender in Lebanon," in Gender and Citizenship in the Middle East, ed. S. Joseph (Syracuse: Syracuse University, 2000): 107-136. 
Draft $-1^{\text {st }}$ Draft

${ }^{85}$ Suad Joseph, Intimate Selving in Arab Families: Gender, Self, and Identity (Syracuse: Syracuse University Press, 1999).

${ }^{86}$ Ibid.

87 Nadine M., “Arab Queer Women and Transgenders Confronting Diverse Religious Fundamentalisms: The Case of Meem in Lebanon, AWID, accessed on 15 September 2018, https://www.awid.org/sites/default/files/atoms/files/feminists_on_the_frontline__arab_queer_women_trans.pdf

88 Annika Rabo, A Shop of One's Own: Independence and Reputation Among Traders in Aleppo (London: I.B. Tauris, 2005); Suad Joseph, "Gender and Citizenship in the Arab World," al-raida, vol. 129-130 (2010): 8-18.

${ }^{89}$ Jana, interview with author, August 2014, Beirut.

${ }^{90}$ Ibid.

${ }^{91}$ Ibid.

${ }^{92}$ Ibid.

${ }^{93}$ Ibid.

${ }^{94}$ Ibid.

95 Simon Haddad, "Christian-Muslim Relations and Attitudes towards the Lebanese State," Journal of Muslim Minority Affairs vol. 21, no. 1 (2001): 131-148; Lucia Volk, "Martyrs at the Margins: The Politics of Neglect in Lebanon's Borderlands," Middle Eastern Studies vol. 45, no. 2: 263-282.

96 There are indications in traditional media and emergent ones that this trend is slowly changing, with an increasing number of projects, notably "eco-tourism" ones, being advertised. In addition, there has been a revival of musical events in the summer in recent years, with a great number of cities of towns attracting large audiences.

${ }^{97}$ Jana, interview with author, august 2014, Beirut. 
Draft $-1^{\text {st }}$ Draft

${ }^{98}$ Gloria Anzaldúa, "Preface: (Un) Natural Bridges, (Un) Safe Spaces," in This Bridge We Call Home: Radical Visions for Transformation, eds. Gloria Anzaldúa and Analouise Keating (New York and London: Routledge, 2002, 1-5.

99 Jana, interview with author, august 2014, Beirut.

100 Ibid.

${ }^{101}$ Ibid.

${ }^{102}$ Ibid.

${ }^{103}$ Ibid.

${ }^{104}$ Elizabeth Freeman, Time Binds: Queer Temporalities, Queer Histories (DukeUniversity Press, 2010), 3.

${ }^{105}$ Lara, interview with the author, June 2014, Tripoli.

${ }^{106}$ Ibid.

${ }^{107}$ Jomana, interview with the author, Beirut, May 2014.

${ }^{108}$ Mireille, interview with the author, near Beirut, April 2015.

${ }^{109}$ Mireille, interview with the author, near Beirut, April 2015.

${ }^{110}$ Jomana, Skype interview with the author, March 2016.

${ }^{111}$ Aline, interview with the author, September 2014, Tripoli.

112 Dona Haraway, "The Promises of Monsters: A Regenerative Politics of Inappropriate/d Others" in The Haraway Reader, ed. D. Haraway (New York: Routledge, 2004): 63-124.

${ }^{113}$ K., interview with the author, Beirut, August 2014.

${ }^{114}$ Carla, interview with author, September 2014, Tripoli.

115 Jean Comaroff, and John L. Comaroff, "Theory from the South: or how Euro-America is Evolving Toward Africa," Anthropological Forum: A Journal of Social Anthropology and Comparative Sociology vol. 22, no. 2 (2012): 113-131 
Draft $-1^{\text {st }}$ Draft

${ }^{116}$ Maya Mikdashi and Jasbir Puar, "Queer Theory and Permanent War," GLQ: a Journal of Lesbian and Gay Studies, vol. 22, no. 2 (2016): 215-222, 215.

117 Jarrod Hayes, Margaret R. Higonnet, and William J. Spurlin, Comparatively Queer: Interrogating Identities Across Time and Cultures (New York: Palgrave Macmillan, 2010)

118 Sandeep Bakshi, Suhraiya Jivraj, and Silvia Posocco, Decolonizing Sexualities: Transnational Perspectives, Critical Interventions (Oxford: Counterpress, 2016).

119 Originally coined by French philospher Henri Lefebre, see Mark Purcell, "Possible Worlds: Henri Lefebvre and the Right to the City," Journal of Urban Affairs vol. 31, no. 1 (213): 414-154.

${ }^{120}$ Michelle Obeid, ed., "Ethnography as Knowledge in the Arab Region," Contemporary Levant vol. 2, no. 1 (2017).

${ }^{121}$ Sertaç Sehlikoglu, "Revisited: Muslim Women’s Agency and Feminist Anthropology," Contemporary Islam vol. 12, no. 1 (2017): 73-92, 83.

${ }^{122}$ Salih, "Bodies that Walk, Bodies that Talk, Bodies that Love," 746.

${ }^{123}$ José Muñoz, "Ephemera as Evidence: Introductory Notes to Queer Notes," Women \& Performance: A Journal of Feminst Theory vol. 8, no. 2 (1996): 5-16.

${ }^{124}$ Ibid., 6.

${ }^{125}$ Morrison et al, 2012.

${ }^{126}$ Muñoz, Cruising Utopia.

${ }^{127}$ Georgis, The Better Story.

${ }^{128}$ Muñoz, Cruising Utopia, 1.

${ }^{129}$ Mikdashi and Puar, Queer Theory and Permanent War.

130 Lila, Abu-Lughod. "The Romance of Resistance: Tracing Transformations of Power Through Bedouin Women," American Ethnologist vol. 17, no.1 (1990): 41-55, 42. 
Draft $-1^{\text {st }}$ Draft

131 Lila Abu-Lughod, Veiled Sentiments: Honor and Poetry in a Bedouin Society (Oakland: University California Press, 1986).

132 Lila Abu-Lughod, "Shifting Politics in Bedouin Love Poetry," in Language and the Politics of Emotions, eds. Lila Abu-Lughod and Catherine Lutz (New York: Cambridge University Press, 1990), 24-45.

${ }^{133}$ Khalili, The Politics of Pleasure.

${ }^{134}$ Ibid., 584.

135 Saba Mahmood, "Feminist Theory, Embodiment, and the Docile Agent: Some Reflections on the Egyptian Islamic Revival," Cultural Anthropology vol. 16, no. 2 (2001): 202-236, 203. 